UDC 005.932

L. R. Strutynska, Cand. Sc. (Tech.), Assoc. Prof., orcid.org/0000-0002-0401-5475,

I. S. Aftanaziv, Dr. Sc. (Tech.), Prof., orcid.org/0000-0003-3484-7966,

O. I. Strogan, Cand. Sc. (Tech.),

orcid.org/0000-0002-1790-6736,

N. V. Ortynska, Dr. Sc. (Jurid.), Assoc. Prof., orcid.org/0000-0002-5061-5340
DOI: $10.29202 /$ nvngu/2018/16

Lviv Polytechnic National University, Lviv, Ukraine e-mail: ivan.aftanaziv@gmail.com

\title{
DETERMINING THE SITES OF OPTIMAL LOCATION OF REGIONAL LOGISTICS CENTERS
}

Based on the analysis of the state of logistics network formation in Ukraine, a conclusion is made regarding the relevance of establishing regional logistics centers. The regional logistics centers are to unite scattered logistic business units of production, processing, transportation and trade enterprises of a certain region and increase economic efficiency of their activities. Structurally, apart from logistics and scheduling departments, the regional logistics centers can include regional centers of commodity distribution networks with distributive warehouses, transportation units for providing transport facilities with their own repair, operation and maintenance services and so forth.

The suggested techniques for selecting and optimizing regional logistics center location are based on the ommodeycal relation of expediency of locating logistics centers to a number of geographic and social factors. It takes into account the population density of the region under consideration, cargo and commodity turnover, possibilities of transport and infrastructure provision for the center's activities and its remoteness from residential areas. The multifunctional mathematical relation of optimization of selecting a site to establish a regional logistics center will allow choosing its location successfully as well as will contribute to increasing its efficiency.

Purpose. To develop methods for defining and optimizing sites of territorial arrangement of functional regional logistics centers of the centralized structure of the logistics network.

Methodology. While developing and studying the mathematical model reflecting dependence of territorial location of a regional logistics center on a range of independent factors, we relied on the theory of scheduling and optimizing a multiple-factor experiment.

Findings. Mathematical relationship has been developed for selecting and optimizing places of territorial arrangement of regional logistics centers. A structure of newly established logistics centers has been suggested; variable factors influencing the expediency of formation of these centers in a particular region have been analyzed. The efficiency of the suggested methods for selecting the location of a regional logistics center has been illustrated using the example of the region of Central Ukraine including Dnipropetrovska, Poltavska, Chernihivska and Kirovohradska Oblasts.

Originality. The idea of establishing regional logistics centers as well as the mathematical model of analysis and optimization of sites of their territorial location has been described by the authors for the first time.

Practical value. The regional logistics centers are to take on the main functional management duties of forming and directing logistics centers of a region as well as duties of pursuing efficient production activities. Development of regional logistics centers will allow increasing the efficiency of logistics networks, make it possible to coordinate ommodties of scattered logistic departments and business units of enterprises of a region. The suggested mathematical model allows making a shrewd choice of a place of locating such a center. While operating a logistics center, the shrewd choice of location will reduce expenditures on transporting goods and cargo.

Keywords: logistics, region, location, network, map, distance

Due to optimization of logistics processes and flows, there increases significance of logistics as an efficient means of improving production and processing activities as well as an important tool of increasing economic efficiency of various industries. Thus, in [1] it is noted that optimization of flow processes in economy has become possible only due to repositioning from quantitative criteria of assessing economic activities to qualitative ones. Regarding the management of flow processes, it is validly stated that operating the flow processes, transforming and integrating them make it a new form of management, which out-performs the traditional forms both by the level of creative potential and by effi-

(c) Strutynska L. R., Aftanaziv I. S., Strogan O. I., Ortynska N. V., 2018 ciency of eventual outcome. A peculiarity of current development of logistics involves the fact that along with traditional material flow, interest sphere of logistics has expanded to include information and financial flows which accompany the material ones, and comparatively recently it has embraced specific service flows [2]. Such a rapid process of logistics development inevitably envisages not only creative re-thinking of its tasks and problems, but also an updated approach to formation of the state's economic policy in the field of logistics.

It is worth recognizing the following as an indisputable fact: at the current stage of the society's economic development logistics is undergoing imminent transformation from a subordinate role of accompanying and servicing trade networks and transportation flow to an 
independent highly-efficient branch of economy [3]. In the near future, Ukraine will also experience these inevitable transformations of tasks and functions of logistics as an independent branch of the national economy. Indeed, due to extremely favorable geographic location at the intersection of both trade and raw material flows, Ukraine has every reason for active investing of foreign capital in such a promising branch of economy as logistics and, respectively, for its rapid development conditioned by this.

Particularly at this responsible stage of formation and development of logistics, there arises an inevitable requirement of establishing powerful regional centers of logistical support all over the country. These so-called "regional logistics centers" would have to unite counterproductive logistic departments and business units of certain production, trade and transportation enterprises and networks at the first stage of their development. Being located in a certain ommodeyically advantageous or commercially powerful manufacturing region of the state, these logistics centers are to organically take upon themselves each and every supervisor responsibility and production function according to their formation, development and improvement. At the first stages, their basis could include, for example, technological parks or distribution centers of the commodity distribution network [4].

Depending on peculiarities of a certain region, logistics networks can be organized as a centralized structure with an integrated powerful logistics center or as a decentralized structure with a number of small logistics business units $[5,6]$. Ukraine's territory mainly belongs to a cohort of densely populated regions. That is why it is evident that an integrated logistics network, which organically unites elements of centralized and decentralized structures, would be relevant.

Objective of the article is development of methods for defining and optimizing sites for arranging multifunctional regional logistics centers of the centralized structure of logistics network.

The tasks of the research included:

- analysis of current methods for identifying places of territorial arrangement of distribution centers of the ommodety distribution network as the basis of formation of regional logistics networks;

- development of a mathematical model of optimizing sites for establishing regional logistics centers of centralized and decentralized structures of logistics network;

- analysis of the optimizing mathematical model of location of regional logistics centers;

- determination of the underlying principles of formation of the structure of multifunctional regional logistics centers.

Analysis of the recent research and publications. While analyzing the formation of present-day logistics networks with their "support points", whose functions are to be performed by powerful regional logistics centers, it would be most expedient to apply the background experience of development of commodity distribution networks with a system of distribution warehouses, the experience of development of technological parks or in- dustrial technology research centers [7] and so forth. At the same time it is worth following the rule that the best network with regional logistics centers will be the one which will provide the highest level of customer service with the lowest total expenditures. Indeed, the formation of networks, through which distribution of material flows will be performed, is an essential and, in many cases, determining element of any logistics system. That is why a great number of leading foreign and domestic scientists paid attention to research on material flows, their optimization in the past $[8,9]$. That is why if a regional logistics center is to be considered the hub of a future innovative structure of not only one particular residential place, but of a whole region, then, undoubtedly, thorough attention should be paid to selecting a place for its territorial arrangement.

The background experience of arrangement of distribution centers and technological parks in Ukrainian cities proves that in the process of their functioning there accumulate a number of major concerns and disadvantages, which undermine the efficiency of production activities [10]. Thus, locating technological parks and logistics centers directly in residential places prevents expanding the amount of their working and serving space because of area restriction. In other words, it hampers the increase in goods and service turnover volume. Locating logistics centers outside towns and cities complicates their employees' commuting to the workplace and, consequently, decreases prospective employees' interest in choosing a logistics center as a stable and long-term job. Out of possible alternatives of arranging a logistics center, namely, close to target markets, in the vicinity of manufacturing or with an intermediate location [8], the latter alternative is obviously preferable.

Another important factor is to be necessarily considered while selecting a site to establish a regional logistics center. This refers to its functional orientation, structure and production activity orientation. It is obvious that at the first stages of their activities these logistics centers will rely on functions of distribution warehouses, will include units of transport provision with departments of their maintenance and repairs, departments of accounting, scheduling and administrative management and others. Since functions and activities of stock centers are primary ones, it is necessary to base on specifics of their activities while analyzing, selecting and optimizing places for establishing the regional centers.

Currently known methods for selecting and optimizing places for distribution centers location (full enumeration method, heuristic method, sample point method and method for determination of "power center") are not relevant in this case for defining a site of territorial location of a regional logistics center. The reason for this is the fact that none of them considers availability of infrastructure and transportation networks on the area in the vicinity of a prospective arrangement of the regional logistics center.

Thus, if the fact of forming commodity distribution networks in the state [9] with distribution centers being an organic constituent of a more powerful logistics network is to be understood as admitted and accomplished, 
then it is necessary to admit an urgent need in developing regional logistics centers. However, despite rather profound research in this field, advanced methodology of a scientifically grounded choice of territorial location of regional logistics centers as well as distribution centers has not been developed yet.

Presentation of the main research. Analyzing the methodology for selecting and optimizing places for establishing regional logistics centers, it is necessary to define precisely their major tasks, structure, territorial subordination and time prerequisites for formation and development. Proceeding from the fact that a basis of a newly established regional logistics center is to be a certain distribution center of commodity distribution network, the logistics center should include, apart from warehouses, business units of transportation service with repair and maintenance services for transportation facilities as well as logistics units for scheduling and optimizing logistic operations. If a regional logistics center is established in a new place, then infrastructure and transport support networks are to be of high priority during the analysis. However, either in the former or latter case, the most important thing is to define areas and trade value for servicing which it is planned to develop a regional logistics center as well as a development strategy for the region. Indeed, development of a powerful regional logistics center is not only a long-term matter, but an expensive one as well. As for the expenses on its establishment, which are conditioned by the requirement for constructing new office and industrial buildings, access roads and transportation routes, they will definitely pay off over decades. That is why a newly established regional logistics center is to focus on servicing a number of large cities and regions, to be located close to power networks, in the vicinity of transportation routes.

According to the suggested methods for selecting and optimizing sites for territorial location of regional logistics centers, the following components of the analysis are to be considered as a matter of priority:

- population density, the total number of logistics service users and the area which is under analysis on expediency of arranging a regional logistics center here;

- planned volume of goods turnover of the region's residential areas;

- planned volume of investments at the state and local levels as well as those from natural and legal persons into formation and development of a regional logistics center;

- availability of networks and mainlines of air, railroad, automobile, overseas and river transportation;

- availability of the infrastructure and networks of resources and power supply services, in particular, water, fuel, gas, electrical power and others.

The original data for the analysis and assessment of the expediency of arrangement of a regional logistics center and succession of selecting the territorial place for its arrangement are as follows:

1. Definition of the territorial boundaries of the region, whose residents will be the primary service users, density of population and the number of logistic service users.
The data for the analysis include geographical and "demographic" maps of the region.

2. Definition of the type of territorial governance of the established logistics center (those of region, oblast or district status), affiliation with the centralized or decentralized structure.

The data for the analysis include the development strategy for the region.

3. Definition of the main types of logistics operations, scheduled volume of goods and cargo turnover.

The data for the analysis include the data from provincial departments of statistical office of the region.

4. Analysis of the availability of transportational routes.

The data for the analysis include the map of transportational routes of the region.

5. Analysis of the infrastructure and availability of networks of resources and power supply services.

The data for the analysis include the map of power lines, gas pipe-lines and water supply systems of the region.

The recommended procedure of analysis and optimization while defining sites for territorial arrangement of regional logistics centers is as follows:

- to define and outline the boundaries of the analyzed region for which an established regional logistics center is to provide service;

- to compile a list of oblast and district centers of the regional area. For example, as an alternative, Dnipro Poltava - Cherkasy - Kropyvnytskyi, and so forth;

- to define the number of citizens of residential places of the selected region;

- to calculate the statistically average population density of the region under analysis;

- to outline cities of oblast status and major cities of the region;

- to define zones of intersection or contact among themselves of the circles which outline the residential centers. The transverse segments of these circles (shaded area) will, in particular, outline the area of expedient territorial arrangement of a regional logistics center;

- maps of the following objects are to be laid down upon the "shaded area" of the geographical map of the region under analysis:

a) automobile roads and transportational routes;

b) railway lines;

c) civil and military airports;

d) power lines;

e) river and sea ports if available;

f) oil pipe-lines, gas pipe-lines and water mains;

- the territory which is located within the "shaded area" of the geographical map and is the closest to the "red lines" of bordering transport and power routes can be considered as being recommended for establishing a regional logistics center. The necessary precondition for this territory includes convenient location and vehicular access.

Desirability $D$ of arranging a regional logistics center in a particular analyzed region is checked by the model which is described by functional connection

$$
D=P_{d} \cdot k_{g t} \cdot\left(K_{t r}+K_{\text {inf. }}\right),
$$


where $P_{d}$ is an average density of the population of the analyzed region; $k_{g t}=\frac{\sum_{3=1}^{n} \frac{T_{1}}{L_{1}}}{n}$ is the indirect coefficient of goods turnover of populated areas of the region; $T_{i}$ is goods turnover of the $i^{\text {th }}$ populated area of the region; $L_{i}$ is the distance from the $i^{\text {th }}$ populated area of the region to the site of the regional logistics center; $\mathrm{n}$ is the number of the analyzed populated areas; $K_{\text {inf. }}$ is the cumulative rate of the infrastructure provision of the residential place or populated area of the region where establishment of a regional logistics center is projected. Its components are equal to a third of a unity element upon the availability of each of three main types of energy provision, in particular, $K_{\text {inf. }}=k_{e l}+k_{\text {gas }}+k_{\text {wat }}=0.333+0.333+$ $+0.333=1$. Thus, given the electrical network with sufficient capacity, $k_{e l}=0.333$, while in the absence of it, $k_{e l}=0$. Similarly, upon the availability of gas supply system $k_{\text {gas }}=0.333$ and water mains $k_{\text {wat }}=0.333 ; K_{\mathrm{tr}}$ is the cumulative rate of transport support of the residential place or populated area of the region where of a regional logistics center is to be established. Its components are inversely proportional to the distance from the projected site of the regional logistics center to the nearest motor or railway transportational routes, to airports, river or sea ports.

The analysis of possible values of desirability factor $D$ of establishing a regional logistics center in a particular region shows that appropriate are the alternatives of territorial arrangement for which the value of desirability $D$ surpasses a hundred of units, that is

$$
D>100 \text {. }
$$

At the same time the more the fitted value of the desirability $D$ surpasses a hundred of units, the better opportunities of a prospective logistics center's viable functioning are and the more expedient its establish- ment exactly in this area appears. In contrast, with the fitted value of the desirability $D$ significantly lower than a hundred of units, the establishment of a regional logistics center here is inexpedient.

According to the mathematical relation (1), which represents the components of desirability $D$ of establishing a logistics center in a particular region, it follows that the population density $P_{d}$ of the region, goods turnover $T_{i}$ of its populated areas, availability of a developed infrastructure as well as transportation routes and transport support, which are considered by the coefficient $K_{t r}$, will affect prospective logistics center's performance favorably. On the other hand, increasing distance $L_{i}$ of the site of the regional logistics center from residential areas, on the contrary, decreases desirability $D$ of logistics center development.

Such influence of different levels of the components on the desirability $D$ of territorial arrangement makes it possible to modify available variants of choice of logistics centers establishment, optimization of separate components (multipliers). This fact gives ground to regard the relation (1) as a certain mathematical optimization model for the procedure of selecting sites of territorial arrangement of regional logistics centers for successful and efficient service to the populated areas of the region.

To check the efficiency of the given mathematical model, let us consider an example of applying the suggested methods for selecting and optimizing sites for establishing a regional logistics center in a densely populated region of Central Ukraine localized by Dnipropetrovska, Poltavska, Cherkaska and Kirovohradska Oblasts. The initial values for computation are presented in Table and shown in Figure.

$$
\begin{aligned}
P_{d}= & \frac{P_{d(\text { Polt. })}+H_{d(\text { Dn. })}+P_{d(\text { Kir. })}+P_{d(\text { Cherk })}}{4}= \\
& =\frac{49.3+101.43+39+58.5}{4}=62,
\end{aligned}
$$

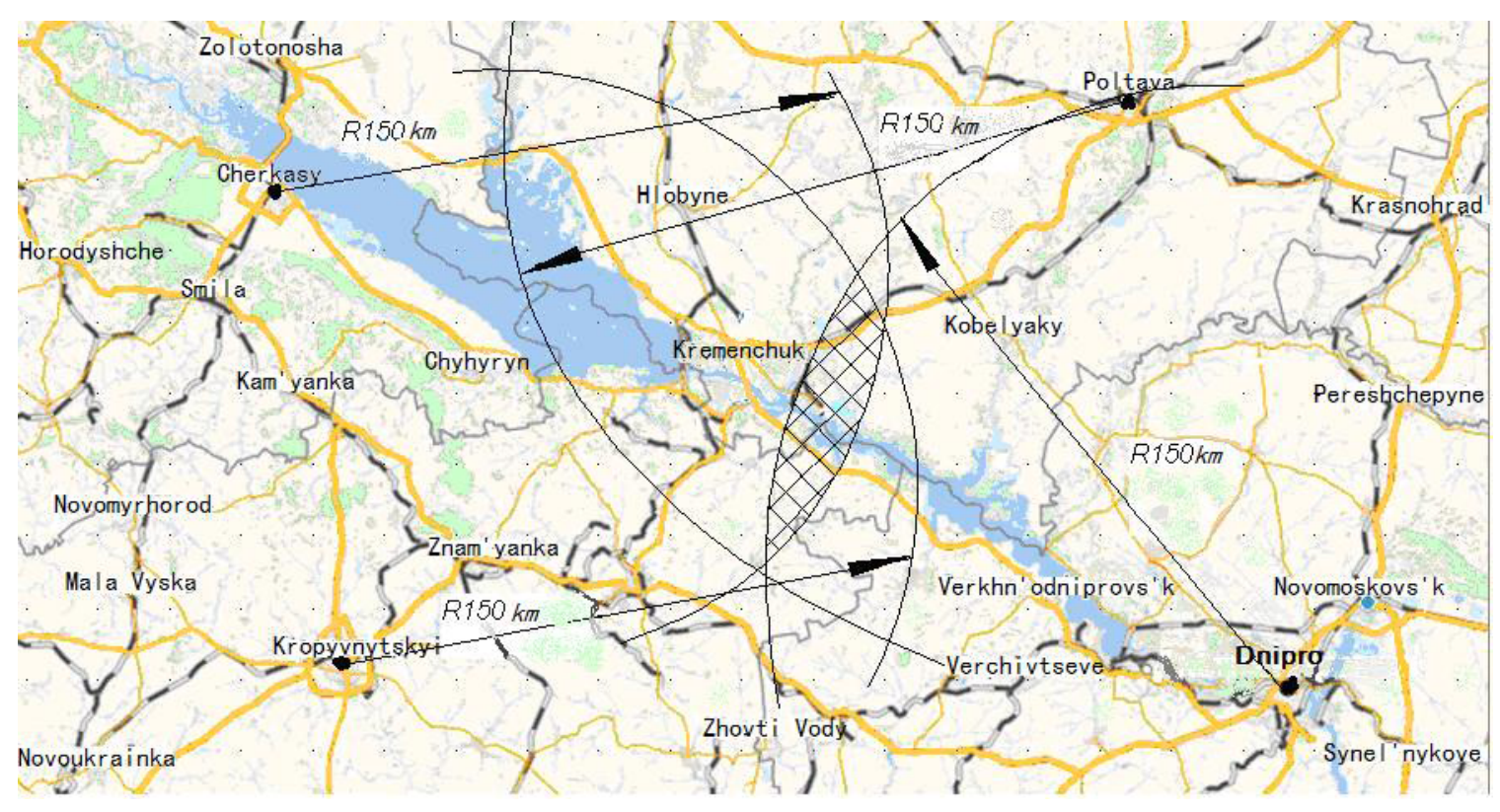

Fig. Statistically average population density of the concerned region 
where $P_{d(\text { (Polt. })}=49.3$ people $/ \mathrm{km}^{2}$ is the population density of Poltavska Oblast; $P_{d(\text { Dn. })}=101.43$ people $/ \mathrm{km}^{2}$ is the population density of Dnipropetrovska Oblast; $P_{d \text { (Kir. })}=39$ people $/ \mathrm{km}^{2}$ is the population density of Kirovohradska Oblast; $P_{d(\text { Cherk. })}=58.5$ people $/ \mathrm{km}^{2}$ is the population density of Cherkaska Oblast.

On the map of Central Ukraine there are arcs of $150 \mathrm{~km}$ radius drawn from cities of oblast status of Dnipro, Poltava, Cherkasy and Kropyvnytskyi as the centers of circles (Figure). The value of the radius of the arcs within $150 \mathrm{~km}$ was opted from considerations of plausible transportation time for transport to get from any of the selected oblast cities to the projected site of prospective regional logistics center establishment. By "plausible transportation time", there is meant the distance from the logistics center to any place of the region which allows loading transport facilities, driving up to the point of delivery of goods or cargo, unloading and getting back to a vehicle fleet based at the logistics center during the daylight hours.

In Figure, the area which is outlined by the arc sections of $150 \mathrm{~km}$ radius is shaded. According to the given methodology, this is the area where it is expedient to establish a regional logistics center which will provide services for up to a 106 thousand $\mathrm{km}^{2}$ region, which is about $1 / 6$ of the whole territory of Ukraine.

Obviously, a designated location of establishing a prospective logistics center in in this particular case is to be on the periphery of Kramatorsk. This city is situated in the zone outlined (shaded) by us; it is more or less equidistant from the selected regional (oblast) centers. Most significantly, it features a proper infrastructure and proximity not only to transportational routes, but to the navigable river Dnipro, by the side of which a river port for the prospective logistics center can be established. The distances from Kramatorsk to the regional centers under consideration are given in Table.

It should be noted that for preliminary assumptions we accept that daily goods turnover $T_{i}$ of the selected regions (oblasts) is proportional to the number of their residents and is calculated within the range of $1 \mathrm{~kg}$ of goods turnover for 10 citizens per day.

The overall indirect coefficient of goods turnover of the prospective logistics center is defined as the mean of the coefficient of goods turnover of the regions (oblasts). That is

$$
\begin{aligned}
& k_{g t .}=\frac{\sum_{i=1}^{n} \frac{T_{i}}{L_{i}}}{i}=\frac{k_{g t(\mathrm{Pol})}+k_{g t(\mathrm{Dn})}+k_{g t(\mathrm{Kir})}+k_{g t(\mathrm{Cherk})}}{4}= \\
& =\frac{\frac{T_{(\mathrm{Pol})}}{L_{(\mathrm{Pol})}}+\frac{T_{(\mathrm{Dn})}}{L_{(\mathrm{Dn})}}+\frac{T_{(\mathrm{Kir})}}{L_{(\mathrm{Kir})}}+\frac{T_{(\mathrm{Cherk})}}{L_{(\mathrm{Cherk})}}}{4}= \\
& =\frac{\frac{144}{113}+\frac{323}{161}+\frac{99.5}{135}+\frac{121}{128}}{4}=\frac{1.3+2+0.74+0.95}{4}=1.25 \text {. }
\end{aligned}
$$

The rate of transport support of Kramatorsk as a site of establishing a regional logistics center is defined according to the relation

$$
\begin{gathered}
K_{t r}=\sum_{i=1}^{n} k_{a i r}+k_{a u}+k_{\text {rail }}+k_{r . p .}= \\
=0.03+0.1+0.1+0.1=0.33
\end{gathered}
$$

where $k_{a u}=\frac{1}{L_{a u}}=\frac{1}{10}=0.1$ is the coefficient of vehicle (automobile) support of transportation service, which considers the distance $L_{a u}=10 \mathrm{~km}$ from the logistics center to the nearest motorway; $k_{\text {rail }}=\frac{1}{L_{\text {rail }}}=\frac{1}{10}=0.1$ is the coefficient of railroad support of transportation service, which considers the distance $L_{\text {rail }}=10 \mathrm{~km}$ from the logistics center to the nearest railway lines; $k_{r . p .}=\frac{1}{L_{r . p .}}=\frac{1}{10}=0.1$ is the coefficient of waterway support of transportation service, which considers the distance $L_{r . p .}=10 \mathrm{~km}$ from the logistics center to the nearest river port;

$$
\begin{aligned}
\sum_{i=1}^{n} k_{\text {air }}= & k_{\text {air }(\mathrm{Dn})}+k_{\text {air }(\mathrm{Kir})}+k_{\text {air }(\mathrm{Pol})}+k_{\text {air }(\mathrm{Cherk})}= \\
= & \frac{1}{L_{(\mathrm{Dn})}}+\frac{1}{L_{(\mathrm{Kir})}}+\frac{1}{L_{(\mathrm{Pol})}}+\frac{1}{L_{(\mathrm{Cherk})}}= \\
= & \frac{1}{161}+\frac{1}{135}+\frac{1}{113}+\frac{1}{128}=0.03,
\end{aligned}
$$

where $\sum_{i=1}^{n} k_{\text {air }}=0.03$ is the coefficient of air transportation support of transportation service, which considers

Table

The original data for calculating the expediency of establishing a regional logistics center

\begin{tabular}{|c|l|c|c|c|c|c|c|}
\hline No. & Oblasts of the region & $\begin{array}{c}\text { The number } \\
\text { of residents, } \\
\text { thousand } \\
\text { people }\end{array}$ & $\begin{array}{c}\text { Area, } \\
\text { thousand } \\
\mathrm{km}^{2}\end{array}$ & $\begin{array}{c}\text { Average } \\
\text { population } \\
\text { density, } P_{D}, \\
\text { people } / \mathrm{km}^{2}\end{array}$ & $\begin{array}{c}\text { Goods } \\
\text { turnover } T_{i}, \\
\text { ton per day }\end{array}$ & $\begin{array}{c}\text { Distance from the } \\
\text { regional center to } \\
\text { the logistics center, } \\
L_{i}, \mathrm{~km}\end{array}$ & $\begin{array}{c}\text { Coefficient of } \\
\text { goods turnover } \\
k_{i}=\frac{T_{i}}{B_{i}}\end{array}$ \\
\hline 1 & Dnipropetrovska Oblast & 3230.4 & 31.9 & 101.43 & 323 & 161 & 2 \\
\hline 2 & Kirovohradska Oblast & 995.2 & 24.6 & 39 & 99.5 & 135 & 0.74 \\
\hline 3 & Poltavska Oblast & 1439 & 28.8 & 49.3 & 144 & 113 & 1.3 \\
\hline 4 & Cherkaska Oblast & 1211 & 20.9 & 58.5 & 121 & 128 & 0.95 \\
\hline
\end{tabular}


the distance from the airports of the regional (oblast) centers to Kramatorsk; $N_{\text {airp }}=4$ is the overall number of airports in the region (one for each oblast centers).

The cumulative rate of the infrastructure provision of Kramatorsk is

$$
K_{\text {inf. }}=k_{\text {el }}+k_{\text {gas }}+k_{\text {wat }}=0.333+0.333+0.333 \approx 1 .
$$

Substituting the defined values of the components to the relation (1), we obtain

$$
D=P_{d} \cdot k_{g t} \cdot\left(K_{t r}+K_{\text {inf. }}\right)=62 \cdot 1.25 \cdot(0.33+1)=103.1 .
$$

Therefore, the desirability of establishing a regional logistics center in Kramatorsk to provide services for Dnipropetrovska, Poltavska, Cherkaska and Kirovohradska Oblasts makes $D=103.1$, which surpasses the minimum allowed $D_{\min }=100$. And this is understandable, since principal railroad lines and motorways go through Kramatorsk, the city has developed a vital infrastructure, in particular, there are high voltage power lines and gas pipelines available. And most importantly, the city is situated by the side of the navigable river and is relatively close (within $100-150 \mathrm{~km}$ ) to the four regional (oblast) centers considered.

Through this example, credibility of variable components of the optimization model shown by the relation (1) can be estimated with comparative ease. In the presented relation, statistically average population density of the region $P_{d}$ is essentially constant and can change considerably within decades only. As for the coefficient of goods turnover $k_{g t}$ and transport support $K_{t r}$, they can change significantly.

Thus, with rapidly decreasing goods turnover between cities and towns of the region, for example, by a quarter, that is with $T_{(\mathrm{Dn} .)}=240$ thousand $\mathrm{m}, T_{\text {( Kir.) }}=$ $=75$ thousand $\mathrm{m}$ and $T_{\text {(Pol.) }}=108$ thousand $\mathrm{m}, T_{\text {(Cherk. })}=$ $=91$ thousand $\mathrm{m}$, the desirability of establishing a regional logistics center in Kramatorsk, which was defined by the relation (1) with other parameters being constant, will make $D=76.7$, which is on the verge of being at risk with $D_{\min }<100$. With goods turnover decreasing by one third $\left(T_{(\text {Dn. })}=216.4\right.$ thousand $\mathrm{m}, T_{\text {(Kir.) }}=66.7$ thousand $\mathrm{m}$ and $T_{(\text {Pol. })}=96.5$ thousand $\mathrm{m}, T_{\text {(Cherk.) }}=81$ thousand $\mathrm{m}$ ), namely, with a rapid decrease in the coefficient of goods turnover down to $k_{g t}=0.83$, the desirability of establishing a regional logistics center here makes $D=68.4$, which is considerably lower than the critical minimum allowed limit $D_{\min }=100$. Therefore, with such insignificant goods turnover between the cities of the considered region, introduction of a centralized structure of logistics network along with establishing a regional logistics center is not relevant. In this particular case it is more expedient to apply logistics networks with a decentralized structure and commodity distribution networks with distribution warehouses within the areas of regional (oblast) cities under analysis.

Influence of the rate $K_{t r}$ of transport support, which considers availability and distance from the logistics center to motorways and transportational routes, airports, river and sea ports, on the expediency of setting a regional logistics center is meaningful. Thus, with increasing remoteness of a regional logistics center from motorways and railroad lines up to $L_{a u}=L_{\text {rail }}=40 \mathrm{~km}$ while there is no river port, the desirability of establishing a logistics center in this city/town goes down to $D=91.5$, namely, it becomes irrelevant. However, it is worth mentioning that the problem of remoteness of the logistics center from motorways and transportational routes can be solved comparatively easily through laying roads and rail tracks to a newly established logistics center.

Similar is the influence of the coefficient $K_{\text {inf }}$ of the infrastructure provision on the desirability of logistic center establishment. With the lack of proper infrastructure provision, that is $K_{\text {inf. }}=0$, conditions for providing life necessities to the operational personnel of the prospective logistics center are worsened crucially. That is why operating the center is out of question until energy resources and water supply networks are provided to the center area.

Therefore, searching and adjusting variable components in the mathematical relation (1) allow optimizing the selection of sites of territorial arrangement of prospective regional logistics centers as well as technological parks of centralized structures of commodity distribution networks.

The suggested methodology and optimization model expressed in terms of mathematical relation (1) can be applied for analysis and search of sites for establishing small distribution warehouses of decentralized structures of commodity distribution networks, which are mostly used in large populated areas. However, critical numeric values of the desirability factor $D$ will differ significantly and require experimental refinement.

Conclusions. The analysis of the present-day state of formation and development of logistics and commodity distribution networks in Ukraine gives evidence of required transition from wide spread, yet inefficient shattered logistics departments and business units of production, processing, and trade enterprises to establishing powerful regional logistics centers. Structurally, the regional logistics centers can be formed on the basis of regional technological parks or distribution warehouses of developed commodity distribution networks and organically combine terminal functions of storage and accumulation of commodities, raw material and products with functions of transport support of their delivery to users and consumers.

The methods for defining an optimal site for establishing regional distribution centers used at present are imperfect, oriented mostly toward background experience and designers' intuition; they are not supported by proper mathematical apparatus. Therefore, they are not suitable for searching sites to establish regional centers. Apart from distribution warehouses, the regional centers are suggested to include their own transportation facilities for cheapening transportation, repair and maintenance services, as well as logistics departments, departments of scheduling and human resourcing and others.

The optimization model of selecting sites of establishing logistics centers is presented as mathematical relation which shows interrelation between the desirability 
$D$ of arranging a logistics center or technological park in a particular region along with the specifics of the region, its simulated population density, distance between cities and towns of the region and coefficient of goods turnover, transport and infrastructure support of populated places of the region.

\section{References.}

1. Savina, N., 2013. Investing into logistic systems. Monograph. Lviv: Vydavnytstvo Lvivskoii Politekhniky.

2. Shcholokova, T. V., 2013. Innovative infrastructure re-engineering as a component of methodology for managing logistic expenses of an enterprise. In: O. V. Manoilenko, ed., 2013. Accounting-analytical procurement of operational control of business entities: present-day state and improvement trends. Kharkive: NTU "KhPI", pp. 132-168.

3. Toluiev, Yu. I., 2016. Methods of simulation modelling of supply chains. Logistics and Supply Chain Management, 4, pp. 8-15.

4. Shcholokova, T. V., 2016. Analysis and algorithm of operating logistic expenses measuring of the universal logistic systems. Marketing and Management of Innovations [online], 2, pp. 162-174. Available at: <http:// mmi.fem.sumdu.edu.ua/ $>$ [Accessed 15 November 2017].

5. Protsenko, O. D. and Protsenko, I. O., 2012. Logistics and supply chain management - future outlook: Macroeconomic aspect. Moscow: Izdatelskii dom "Delo" [online]. Available at: <http://www.litres.ru/ i-o-procenko-8980132> [Accessed 2 October 2017].

6. Schreibfeder, J., 2016. Achieving Effective Inventory Management. Translated from English by Yu. Orlova. Moscow: Alpina Publisher.

7. Slone, R., J. Paul Dittmann, J. P. and Mentzer, J. T., 2015. The New Supply Chain Agenda: The Five Steps That Drive Real Value. Translated from English. Moscow: Alpina Publisher.

8. Bowersox, D. and Closs, D., 2017. Logistical management: The integrated supply chain process. Translated from English. Moscow: Olimp.

9. Frazelle, E., 2016. World-Class Warehousing and Material Handling. Translated from English by D. Liubovina. Moscow: Alpina Publisher.

10. Gwynne, R., 2017. Warehouse management: A Complete Guide to Improving Efficiency and Minimizing Costs in the Modern Warehouse. Translated from English by M. Vlasov. Moscow: EKSMO.

\section{Визначення місць оптимального розташування регіональних логістичних центрів}

\section{Л. Р. Струтинська, І. С.Афтаназів, О.І. Строган, Н. В. Ортинська}

Національний університет „Львівська політехніка“, м. Львів, Україна, e-mail: ivan.aftanaziv@gmail.com

На підставі аналізу стану формування в Україні логістичних мереж зроблено висновок щодо потре- би у створенні регіональних логістичних центрів. Регіональні логістичні центри покликані об'єднати розрізнені логістичні відділення й підрозділи виробничих, переробних, транспортних і торговельних підприємств певного регіону та підвищити економічну ефективність їх діяльності. Структурно, крім відділень логістики та планування, регіональні логістичні центри можуть включати регіональні центри товаропровідних мереж із розподільчими складськими приміщеннями, транспортні підрозділи для забезпечення перевезень із власними службами ремонту, обслуговування та експлуатації транспорту тощо.

Запропонована методика вибору та оптимізації місць територіального розташування регіональних логістичних центрів грунтується на математичній залежності доцільності розміщення логістичного центру від ряду географічних і соціальних чинників. Вона враховує густоту населення аналізованого регіону, обсяги вантажо- й товарообігу, спроможність транспортного та інфраструктурного забезпечення діяльності центру та його віддаленість від населених пунктів. Багатофункціональна математична залежність оптимізації вибору місця облаштування регіонального логістичного центру дозволить не тільки вдало обрати його місце розташування, але й сприятиме підвищенню ефективності діяльності.

Мета. Створення методики визначення та оптимізації місць територіального облаштування багатофункціональних регіональних логістичних центрів централізованої структури логістичної мережі.

Методика. При побудові й дослідженнях математичної моделі, що відображає залежність територіального вибору місця розташування регіонального логістичного центру від ряду незалежних чинників, спиралися на теорію планування та оптимізації багатофакторного експерименту.

Результати. Розроблена математична залежність для вибору та оптимізації місць територіального облаштування регіональних логістичних центрів. Запропонована структура новостворених логістичних центрів, проаналізовані перемінні чинники, що впливають на доцільність формування в конкретному регіоні цих центрів. Ефективність запропонованої методики вибору місць розташування регіонального логістичного центру проілюстрована на прикладі регіону центральної України, що включає Дніпропетровську, Полтавську, Чернігівську й Кіровоградську області.

Наукова новизна. Ідея створення регіональних логістичних центрів, а також математична модель аналізу та оптимізації місць їх територіального розташування озвучена та описана авторами вперше.

Практична значимість. Регіональні логістичні центри покликані перейняти на себе не тільки основні управлінські функціональні обов'язки формування й керівництва логістичними мережами регіону, але й провадження безпосередньо ефективної виробничої діяльності. Створення регіональних логістичних центрів дозволить підвищи- 
ти ефективність логістичних мереж, надасть можливість скоординувати діяльність роздроблених логістичних відділень і підрозділів підприємств регіону. Запропонована математична модель дозволяє здійснити вдалий вибір місця розташування регіонального логістичного центру. У процесі експлуатації логістичного центру вдалий вибір місця його розташування скоротить витрати на перевезення товарів і вантажів.

Ключові слова: логістика, регіон, місце розташування, мережка, карта, відстань

\section{Определение мест оптимального расположения региональных логистических центров}

\section{Л. Р. Струтинская, И. С. Афтаназив, О. И. Строган, Н. В. Ортынская}

Национальный университет „Львовская политехника“, г. Львов, Украина, e-mail: ivan.aftanaziv@gmail.com

На основании анализа состояния формирования в Украине логистических сетей сделан вывод о необходимости создания региональных логистических центров. Региональные логистические центры призваны объединить разрозненные логистические отделения и подразделения производственных, перерабатывающих, транспортных и торговых предприятий определенного региона и повысить экономическую эффективность их деятельности. Структурно, кроме отделений логистики и планирования, региональные логистические центры могут включать региональные центры товаропроводящих сетей с распределительными складскими помещениями, транспортные подразделения для обеспечения перевозок с собственными службами ремонта, обслуживания и эксплуатации транспорта и тому подобное.

Предложенная методика выбора и оптимизации мест территориального расположения региональных логистических центров основывается на математической зависимости целесообразности размещения логистического центра от ряда географических и социальных факторов. Она учитывает плотность населения рассматриваемого региона, объемы грузо- и товарооборота, возможности транспортного и инфраструктурного обеспечения деятельности центра и его удаленность от населенных пунктов. Многофункциональная математическая зависимость оптимизации выбора места обустройства регионального логистического центра позволит не только удачно выбрать его месторасположе- ние, но и будет способствовать повышению эффективности деятельности.

Цель. Создание методики определения и оптимизации мест территориального обустройства функциональных региональных логистических центров централизованной структуры логистической сети.

Методика. При построении и исследованиях математической модели, отражающей зависимость территориального выбора места расположения регионального логистического центра от ряда независимых факторов, опирались на теорию планирования и оптимизации многофакторного эксперимента.

Результаты. Разработана математическая зависимость для выбора и оптимизации мест территориального обустройства региональных логистических центров. Предложена структура вновь создаваемых логистических центров, проанализированы переменные факторы, влияющие на целесообразность формирования в конкретном регионе этих центров. Эффективность предложенной методики выбора мест расположения регионального логистического центра проиллюстрирована на примере региона центральной Украины, включающем Днепропетровскую, Полтавскую, Черниговскую и Кировоградскую области.

Научная новизна. Идея создания региональных логистических центров, а также математическая модель анализа и оптимизации мест их территориального расположения описана авторами впервые.

Практическая значимость. Региональные логистические центры призваны взять на себя не только основные управленческие функциональные обязанности формирования и руководства логистическими сетями региона, а и осуществление эффективной производственной деятельности. Создание региональных логистических центров позволит повысить эффективность логистических сетей, даст возможность скоординировать деятельность разрозненных логистических отделений и подразделений предприятий региона. Предложенная математическая модель разрешает осуществить удачный выбор места расположения такого центра. В процессе его эксплуатации логистического центра удачный выбор месторасположения сократит расходы на перевозку товаров и грузов.

Ключевые слова: логистика, регион, месторасположение, сеть, карта, расстояние

Рекомендовано до публікації докт. екон. наук О.П.Крайником. Дата надходження рукопису 17.11.17. 